\title{
Estimation of heavy metal contamination in the Hindon River, India: an environmetric approach
}

\author{
Saurabh Mishra ${ }^{1,2} \cdot$ Amit Kumar $^{3,5}\left[\right.$ Prabhakar Shukla ${ }^{4,5}$
}

Received: 23 June 2020 / Accepted: 18 November 2020 / Published online: 4 December 2020

(c) The Author(s) 2020

\begin{abstract}
The Hindon River is a major freshwater resource predominantly for the rural population of the western region in Uttar Pradesh, India. The river receives industrial wastewaters having heavy metals concentration at potentially toxic levels. The focus of this study is to estimate the heavy metals (such as $\mathrm{Fe}, \mathrm{Cu}, \mathrm{Zn}$ and $\mathrm{Cr}$ ) contamination in the Hindon River using Nemerow pollution index followed by environmetrics to identify their pollution source. The water samples are collected from 28 industrial discharge sites in the river to analyze metals concentration during pre- and post-monsoon months. The estimated Nemerow pollution index value is more than 3 indicating severely contaminated river water. Principal component analysis results confirm that $\mathrm{Fe}$ and $\mathrm{Cu}$ are the major contaminants in the river, which indicates the direct input of wastewater from electroplating industries. Therefore, it is suggested that a strategic eco-conservation plan should be formulated and implemented in advance to prevent the deterioration of the water quality and aquatic life.
\end{abstract}

Keywords Hindon River $\cdot$ Heavy metal $\cdot$ Pollution index $\cdot$ PCA

\section{Introduction}

The quality of water is the foremost basic necessity for flourishing aquatic diversity and sustainable eco-development of human civilization and water resources management. Rapid urbanization, industrial advancement and water shortage deteriorate the freshwater bodies in the current world and provoked serious research concerns to safeguard natural

Amit Kumar

amitkdah@nuist.edu.cn; amit.ag109@gmail.com

College of Environment, Hohai University, Nanjing 210098, Jiangsu Province, China

2 Department of Polymer and Process Engineering, Indian Institute of Technology Roorkee, Saharanpur Campus, Saharanpur, Uttar Pradesh 247001, India

3 School of Hydrology and Water Resources, Nanjing University of Information Science and Technology, Nanjing 210044, Jiangsu Province, China

4 Water Security \& Sustainable Development Hub, Indian Institute of Technology Delhi, Hauz Khas, New Delhi 110016, India

5 Biomass and Ecosystem Lab, Department of Hydro and Renewable Energy, Indian Institute of Technology Roorkee, Roorkee, Uttarakhand 247667, India resources and to promote sustainable environmental management (Kumar et al. 2017a; Lone et al. 2020). In the developing world, rivers flowing through urban areas are facing the threat of extinction due to endpoint discharge of partially/untreated effluents from the point and/or nonpoint sources (Mishra and Kumar 2020). In India, the direct urban runoffs and sewerage disposal in the freshwater ecosystem (e.g., river, lakes, reservoirs) are the major challenging threats in deteriorating water quality and ecological health of the aquatic ecosystem (Singh et al. 2020). In recent decades, the heavy metal contamination of surface freshwater bodies, especially rivers, has been hot spots of current research (Mishra et al. 2016a; Kumar et al. 2017b). The heavy metals are added into the river system (by anthropogenic and natural sources) and are distributed either in the aqueous phase, suspended stage, or settle down in the riverbed sediments (Kumar et al. 2017c). Under certain environmental conditions, accumulated heavy metals in the river systems lead to ecological disturbances (Yang et al. 2013; Adimalla 2020). Due to bioaccumulation capacity and the environmental persistence of heavy metals, it has been given special attention to know the potential risk of hazardous heavy elements in water bodies (Alves et al. 2014; Misaghi et al. 2017; Kumar et al. 2020b,c). In this regard, multidisciplinary analytical methodologies based on physiochemical, biological and 
eco-toxicology datasets have been developed around the world through triad approaches so that a strategic catchment area treatment plan could be made in advance (Kumar et al. 2020a). However, due to the rapid growth in number of toxic chemicals compounds potentially render the complete chemical characterization of contaminants (Vink et al. 1999; Singh et al. 2019).

In India, major industrial operations which required a huge amount of freshwater are still dependent upon the rivers; hence, it is essential to study the nutrient loading and its potential sources, systemically (Kaushik et al. 2009; Barnwal et al. 2015). Considering the ecological asset, several studies have been reported in the literature related to the assessment of water quality and heavy metal contamination in benthic sediment of Hindon River (Jain and Sharma 2001; Jose et al. 2014; Nur et al. 2015; Chabukdhara and Nema 2012; Wang et al. 2015). But, a comprehensive study related to the assessment of the heavy metal contamination in the subsurface water of Hindon River along the stretches has not been reported yet. The raw datasets of metals concentration were used to evaluate Nemerow pollution index, which classifies the overall contamination level in the Hindon River in single numeric terms (Mishra et al. 2016b). During the analysis, composite data matrices of heavy metal concentration were difficult to illustrate, interpret and draw meaningful conclusions. Therefore, principal component analysis (PCA) is performed to simplify the interpretation of complex data matrices of water quality and the ecological status of any river (Mishra et al. 2018; Turunen et al. 2020; Kumar and Mishra 2020). PCA has been carried out to identify the possible input sources of heavy metal contaminants in the Hindon River. Identification of metal input sources could give reliable information for better management and conservation of water resources as well as useful to develop a rapid solution to mitigate the problems in effective ways (Simeonov et al. 2004; Dalakoti et al. 2015; Lone et al. 2020). Considering the above research gaps, the present study has been performed to estimate the heavy metals (such as $\mathrm{Fe}, \mathrm{Cu}, \mathrm{Cr}$ and $\mathrm{Zn}$ ) concentration in the subsurface water of Hindon River along the stretches so that its medium or long-term ecological risk could be reduced.

\section{Materials and methods}

\section{Detail of water sampling locations}

The Hindon River is a major tributary of the Yamuna River, flows in the western part of Indo-Gangetic plain. It is a completely rainfed seasonal river that covers a catchment area of about $5000 \mathrm{~km}^{2}$, for length $260 \mathrm{~km}$ and lies between latitude $28^{\circ} 04^{\prime}-35^{\circ} 05^{\prime} \mathrm{N}$ and longitude $77^{\circ} 04^{\prime} \mathrm{E}-77^{\circ} 08^{\prime} \mathrm{E}$. The average rainfall of the river catchment is $\sim 1000 \mathrm{~mm}$. The Hindon River basin lies in six different districts starting from Saharanpur via Muzaffarnagar, via Meerut, via Baghpat, via Ghaziabad, via Gautam Buddh Nagar in western Uttar Pradesh and final merges in the Yamuna River at outskirt of Delhi. There are two main tributaries of Hindon River (Krishna and Kali). The Kali merges in the Hindon River near Barnava village, while Krishna River joins Hindon River near Binauli village in Meerut district. The densely populated river basin has very fertile land where agricultural practices have been actively flourishing, which also supports the growth of industries. However, the discharge of wastewater from domestic, municipal, agriculture and industrial sectors laden with heavy metals concentration has significantly affected the water quality in the river. The major sources of pollution are coming from sugar distilleries, pulp and paper, and others join the river through various drains network (Nagdev, Dhamola and Barnawa nalla). Considering the joining sites of major drains and ecological signification, the sampling locations were chosen to collect the river water samples, whose details are shown in Table 1 and depicted in Fig. 1.

\section{Sampling, data collection and analysis}

The composite water samples were collected (using an acid-washed plastic container) during day time at $10 \mathrm{am}$ near the shoreline at each sampling locations (R1-R28) in the Hindon River during pre-and post-monsoon months of year 2013-14. The collected composite samples were filtered through Whatman no. 42 papers followed by preservation with $6 \mathrm{~N} \mathrm{HNO}_{3}$ in acid rinsed containers. The containers were stored at $4{ }^{\circ} \mathrm{C}$ temperature without freezing and transported to the laboratory within $24 \mathrm{~h}$ to avoid unpredictable changes in characteristics. The water samples were analyzed in the laboratory by following the procedure reported by APHA (2011). Atomic absorption spectrophotometer (AAS, GBC, Avanta) equipped with a specific lamp for the particular metal was used for the analysis of heavy metals concentration in water samples. The overall recovery rates (mean $\pm \mathrm{SD}$ ) of $\mathrm{Fe}, \mathrm{Zn}, \mathrm{Cr}$ and $\mathrm{Cu}$, were $92 \pm 5.4,89 \pm 6.9,93 \pm 5.4$ and $94 \pm 3.2 \%$, respectively, where limit of detection of $\mathrm{Fe}, \mathrm{Zn}, \mathrm{Cr}$ and $\mathrm{Cu}$ in aqueous were $0.03,0.004,0.002,0.003 \mathrm{mg} / \mathrm{L}$, respectively. Each experimental analysis was conducted in three replicates, and the mean values of the raw data for each sample were considered for further analysis in this study. The detailed procedure adopted to carry out this study has been presented in the form of a flowchart, as shown in Fig. 2. All the graphs have been constructed using MS Excel version 7 software to represent their actual mean 
Table 1 Different surface water sampling locations

\begin{tabular}{|c|c|c|}
\hline Location code & Sampling location & Coordinates \\
\hline R1 & Atali village & $29^{\circ} 26^{\prime} 45^{\prime \prime}-77^{\circ} 29^{\prime} 43^{\prime \prime}$ \\
\hline R2 & Banganga nala & $29^{\circ} 65^{\prime} 04^{\prime \prime}-77^{\circ} 26^{\prime} 25^{\prime \prime}$ \\
\hline R3 & Krishna River & $29^{\circ} 60^{\prime} 53^{\prime \prime}-77^{\circ} 25^{\prime} 52^{\prime \prime}$ \\
\hline R4 & Kalina village drain & $28^{\circ} 58^{\prime} 30^{\prime \prime}-77^{\circ} 27^{\prime} 58^{\prime \prime}$ \\
\hline R5 & Habibpur nala & $28^{\circ} 56^{\prime} 31^{\prime \prime}-77^{\circ} 27^{\prime} 38^{\prime \prime}$ \\
\hline R6 & Siwat drain & $28^{\circ} 56^{\prime} 46 .^{\prime \prime}-77^{\circ} 27^{\prime} 40^{\prime \prime}$ \\
\hline R7 & Daula drain & $28^{\circ} 52^{\prime} 46^{\prime \prime}-77^{\circ} 25^{\prime} 38^{\prime \prime}$ \\
\hline R8 & Tera drain & $28^{\circ} 47^{\prime} 49^{\prime \prime}-77^{\circ} 23^{\prime} 25^{\prime \prime}$ \\
\hline R9 & Sonda drain & $28^{\circ} 43^{\prime} 58^{\prime \prime}-77^{\circ} 23^{\prime} 06^{\prime \prime}$ \\
\hline R10 & Drain Upstream Karedha village & $28^{\circ} 41^{\prime} 05^{\prime \prime}-77^{\circ} 23^{\prime} 36^{\prime \prime}$ \\
\hline $\mathrm{R} 11$ and R12 & $\begin{array}{l}\text { Mohannagar area in Ghaziabad where various polluting indus- } \\
\text { tries are located }\end{array}$ & $28^{\circ} 39^{\prime} 56^{\prime \prime}-77^{\circ} 23^{\prime} 57^{\prime \prime}$ \\
\hline R13 & It is a downstream site nearby railway bridge of Mohannagar & $28^{\circ} 39^{\prime} 59^{\prime \prime}-77^{\circ} 23^{\prime} 25^{\prime \prime}$ \\
\hline $\mathrm{R} 14$ & Downstream site which is near Hapur bypass & $28^{\circ} 38^{\prime} 04^{\prime \prime}-77^{\circ} 23^{\prime} 41^{\prime \prime}$ \\
\hline R15 & Downstream site and located near Haibatpur village & $28^{\circ} 36^{\prime} 32^{\prime \prime}-77^{\circ} 24^{\prime} 15^{\prime \prime}$ \\
\hline R16 & A branch of Hindon located near Ghazipur landfill site & $28^{\circ} 36^{\prime} 10^{\prime \prime}-77^{\circ} 25^{\prime} 26^{\prime \prime}$ \\
\hline R17 & Pratap Vihar Drain & $28^{\circ} 38^{\prime} 24^{\prime \prime}-77^{\circ} 23^{\prime} 22^{\prime \prime}$ \\
\hline $\mathrm{R} 18$ & Bahlolpur Drain & $28^{\circ} 38^{\prime} 22^{\prime \prime}-77^{\circ} 23^{\prime} 23^{\prime \prime}$ \\
\hline R19 & Gaur City Drain & $28^{\circ} 36^{\prime} 34^{\prime \prime}-77^{\circ} 24^{\prime} 16^{\prime \prime}$ \\
\hline $\mathrm{R} 20$ & Bisrakh Jalalpur Drain & $28^{\circ} 35^{\prime} 59^{\prime \prime}-77^{\circ} 25^{\prime} 26^{\prime \prime}$ \\
\hline $\mathrm{R} 21$ & Kulesara drain & $28^{\circ} 33^{\prime} 40^{\prime \prime}-77^{\circ} 25^{\prime} 21^{\prime \prime}$ \\
\hline R22 & Malakpur Drain & $28^{\circ} 31^{\prime} 11^{\prime \prime}-77^{\circ} 25^{\prime} 59^{\prime \prime}$ \\
\hline $\mathrm{R} 23$ & Gujarpur Drain & $28^{\circ} 30^{\prime} 00^{\prime \prime}-77^{\circ} 27^{\prime} 00^{\prime \prime}$ \\
\hline $\mathrm{R} 24$ & Badauli Bangar Drain & $28^{\circ} 28^{\prime} 48^{\prime \prime}-77^{\circ} 28^{\prime} 27^{\prime \prime}$ \\
\hline $\mathrm{R} 25$ & Pitarsi Sewage Drain & $28^{\circ} 27^{\prime} 36^{\prime \prime}-77^{\circ} 28^{\prime} 36^{\prime \prime}$ \\
\hline R26 & Bhaggal Sewage Drain & $28^{\circ} 25^{\prime} 47^{\prime \prime}-77^{\circ} 29^{\prime} 41^{\prime \prime}$ \\
\hline R27 & GN Sewage Drain & $28^{\circ} 25^{\prime} 14^{\prime \prime}-77^{\circ} 30^{\prime} 21^{\prime \prime}$ \\
\hline $\mathrm{R} 28$ & Confluence of Hindon and Yamuna River & $28^{\circ} 24^{\prime} 47^{\prime \prime}-77^{\circ} 29^{\prime} 45^{\prime \prime}$ \\
\hline
\end{tabular}

concentration at a specific sampling location, as shown in Fig. 3.

\section{Evaluation of pollution index}

The assessment of the overall contamination level and heavy metal enrichment in the Hindon River water was performed using the contamination index (CI) and Nemerow pollution index (PI) illustrated by Yang et al. (2013). The $\mathrm{CI}$ and PI were evaluated using the raw data of heavy metals concentration. Primarily, the individual pollution index (Pi) of heavy metals was calculated against the permissible concentration of respective heavy metal in drinking water quality (BIS 2011; WHO 2011) using Eq. 1 and further CI was evaluated using Eq. 2, mathematically expressed as:
$\mathrm{CI}=\frac{1}{4} \sum \mathrm{Pi}$

The CI values represent the level of contamination in the water as $\mathrm{CI}$ value $>5$ (contaminated), $5 \leq \mathrm{CI}$ value $>1$ (slightly contaminated) and $\mathrm{CI} \leq 1$ (not contaminated). Furthermore, to elaborate the enormity contribution of individual toxic heavy metal in the river water, PI was evaluated as a single factor index, which can be calculated using Eq. 3, mathematically expressed as:

$\mathrm{PI}=\sqrt{\frac{\left(\mathrm{Pi}_{\text {max }}^{2}+\mathrm{CI}^{2}\right)}{2}}$

where $\mathrm{Pi}_{\max }$ denote the maximum value of $\mathrm{Pi}$ among all four heavy metals evaluated at the particular sampling

$\mathrm{PI}=\frac{\text { estimated concentration of individual heavy metal }}{\text { standard permisible concentration of heavy metal in drinking water }}$ 


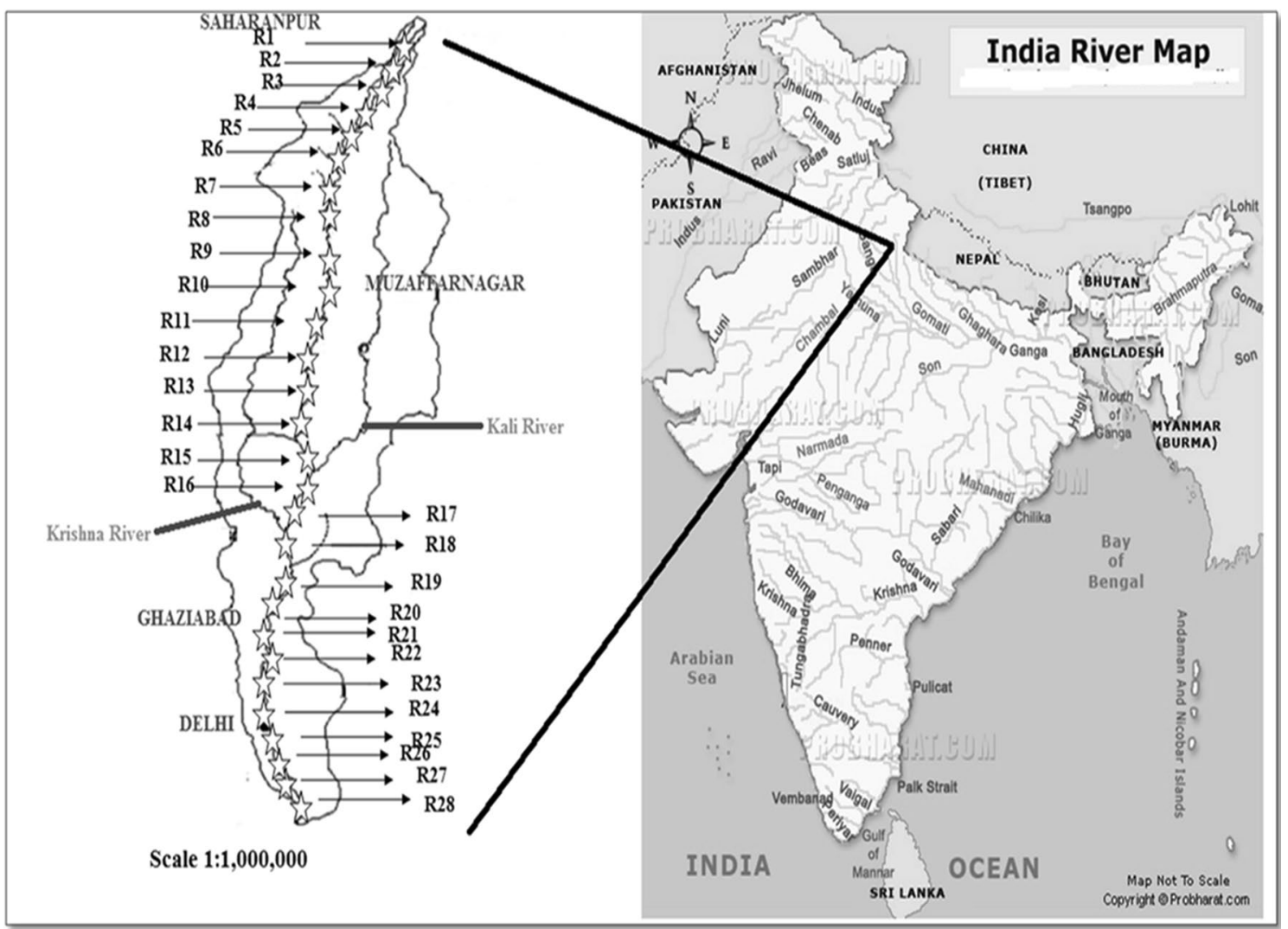

Fig. 1 Schematic diagram of sampling locations in the stretch of Hindon River

Fig. 2 Flow diagram of methodologies adopted in this study

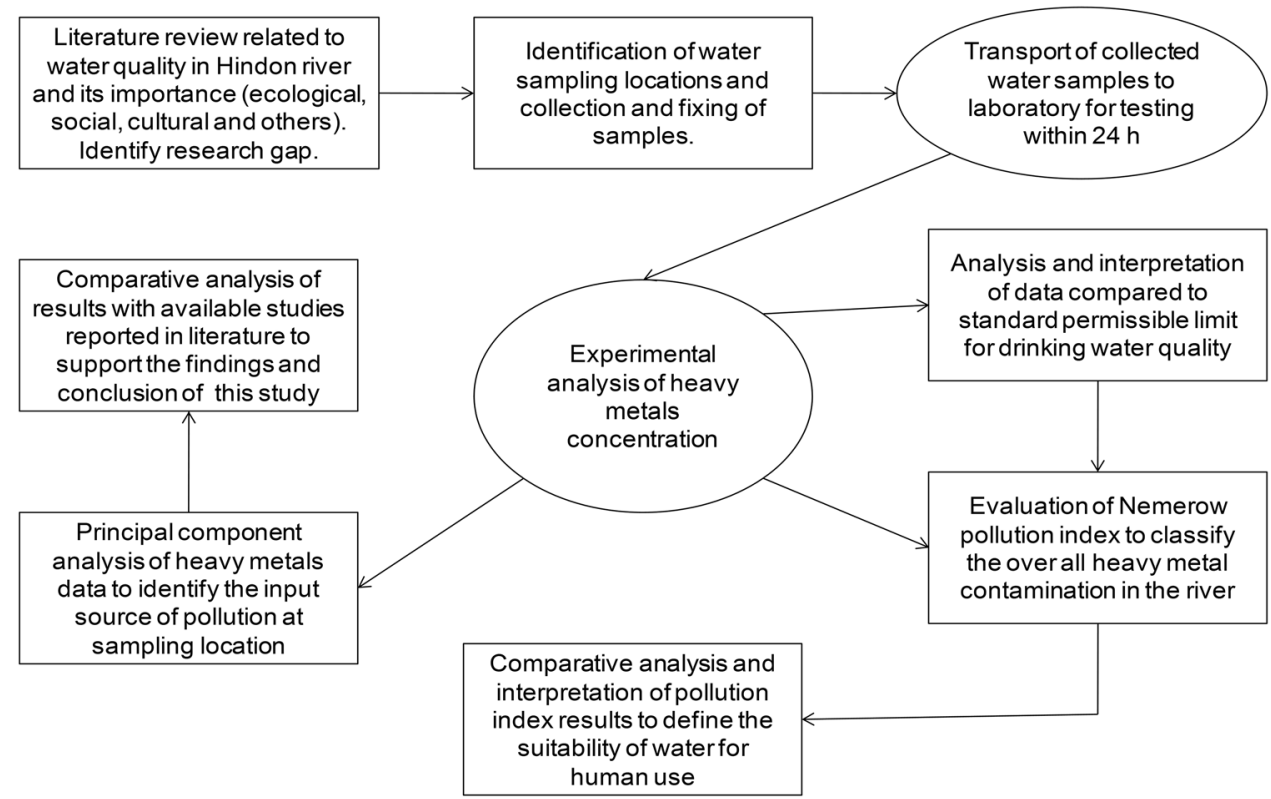

drinking) and PI $>3$ (severely contaminated water, unsuitable for drinking). location. PI value classifies the overall water quality as PI value $\leq 1$ (not contaminated, drinkable water); $3 \leq$ PI value $>1$ (slightly contaminated water, unsuitable for 
Fig. 3 Metal concentration during pre- (a) and post- (b) monsoon months at different sampling locations

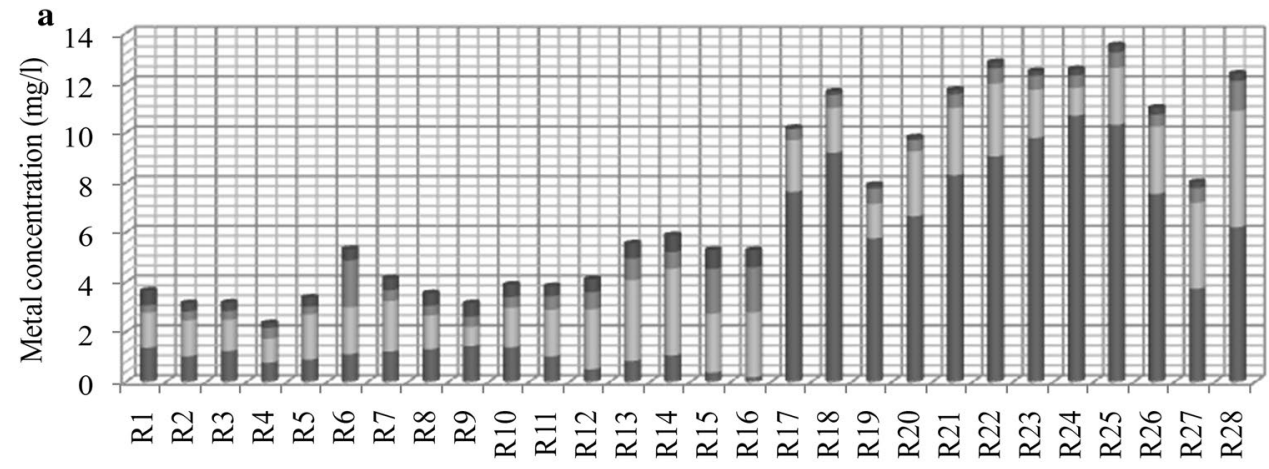

b

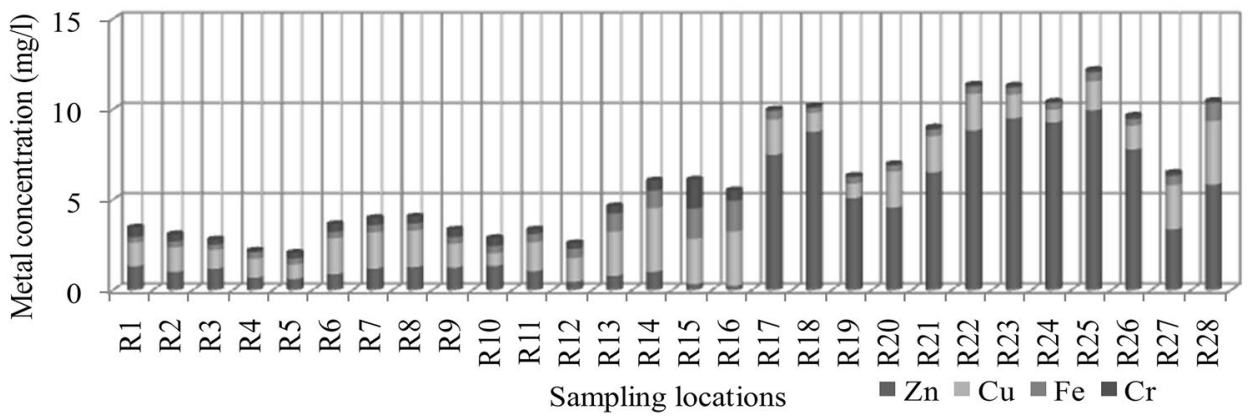

\section{Principal component analysis}

Principal component analysis (PCA) is frequently used to identify the input source of nutrients in the freshwater bodies that could provide meaningful information for eco-conservation and management. In this study, the data of heavy metals $(\mathrm{Cu}, \mathrm{Zn}, \mathrm{Fe}$ and $\mathrm{Cr})$ concentration obtained during laboratory analysis were used to perform Pearson's correlation coefficients and PCA using SPSS version 17.0 software. The principal components (PCs) extracted during PCA of heavy metals datasets for all sampling locations were analyzed to assess variations in heavy metals concentration in the river water during the sampling period.

\section{Results and discussion}

\section{Assessment of heavy metal contamination}

The estimated heavy metals ( $\mathrm{Fe}, \mathrm{Cr}, \mathrm{Cu}$ and $\mathrm{Zn}$ ) concentrations were primarily compared with their respective permissible limit for drinkable water to identify the major contaminant in the Hindon River. Considerably, the estimated values of all heavy metals were found above their permissible value at each sampling location in both pre- and post-monsoon months. The results reveal that the river water is enriched with metals and unsuitable for drinking. To know the overall contamination level in the Hindon River, PI and CI were calculated using the raw datasets of four heavy metals $(\mathrm{Fe}, \mathrm{Cr}, \mathrm{Cu}$ and $\mathrm{Zn})$ collected at all locations during pre- and post-monsoon months (Table 2). The mean value of $\mathrm{CI}$ for all sampling locations (R1 to R28) was falling between 11.53 and $12.79(\mathrm{CI}>5)$ during pre-and postmonsoon months, respectively, indicating contaminated water. Similarly, level of contamination was checked through PI, the estimated result is falling between 31.30 and 30.48 (PI>3) for the respective period, indicating severe contamination of river water. The variability in the PI value at sampling locations in the studied period is graphically shown in Fig. 4.

It could be observed that there was a minor decrease in contamination level in river water during post-monsoon compared to pre-monsoon season at most of the sampling locations. This decrease in the contamination level might be due to dilution of river water that occurred during the monsoon months (Lasagna et al. 2013; Turunen et al. 2020).

Comparably, an increase in contamination level was observed at eight sampling locations (R8, R9, R14, R15, $\mathrm{R} 16, \mathrm{R} 22, \mathrm{R} 27$ and $\mathrm{R} 28$ ) during post-monsoon than to premonsoon months. It could be due to the geographical feature that supports the accumulation of water at the respective locations (Islam et al. 2015). The average PI at R1 to R16 locations during the pre- and post-monsoon months were found as 28.38 and 26.07, respectively, while PI for R17-R28 sites was found to be 35.19 and 36.35 , respectively. The results indicate that the R17-R28 sites were more affected by industrialization (major industries are located in the stretch) and geographical variations, which are beyond the assimilative or carrying capacity of the river. The present results support the previous findings of the pollution status in the Hindon River reported by researchers of different

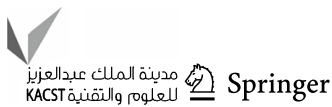


Table 2 Evaluation of CI and PI during pre- and post-monsoon months (2013-14)

\begin{tabular}{|c|c|c|c|c|c|c|c|c|c|c|c|c|c|c|}
\hline \multirow{2}{*}{$\begin{array}{l}\text { Sampling } \\
\text { location }\end{array}$} & \multicolumn{2}{|l|}{ Pi Zn } & \multicolumn{2}{|l|}{$\mathrm{Pi} \mathrm{Fe}$} & \multicolumn{2}{|l|}{$\mathrm{Pi} \mathrm{Fe}$} & \multicolumn{2}{|l|}{$\mathrm{Pi} \mathrm{Cr}$} & \multicolumn{2}{|l|}{ CI } & \multicolumn{2}{|l|}{ Pi Max } & \multicolumn{2}{|l|}{ PI } \\
\hline & Pre & Post & Pre & Post & Pre & Post & Pre & Post & Pre & Post & Pre & Post & Pre & Post \\
\hline $\mathrm{R} 1$ & 0.27 & 0.26 & 28.00 & 26.20 & 1.00 & 1.00 & 11.80 & 11.00 & 10.27 & 9.62 & 28.00 & 26.20 & 21.09 & 19.73 \\
\hline $\mathrm{R} 2$ & 0.20 & 0.20 & 28.80 & 27.00 & 1.20 & 1.13 & 6.80 & 8.20 & 9.25 & 9.13 & 28.80 & 27.00 & 21.39 & 20.15 \\
\hline R3 & 0.25 & 0.23 & 25.00 & 21.00 & 1.20 & 0.93 & 6.80 & 6.20 & 8.31 & 7.09 & 25.00 & 21.00 & 18.63 & 15.67 \\
\hline R4 & 0.15 & 0.14 & 19.20 & 21.00 & 1.43 & 1.20 & 3.80 & 2.00 & 6.15 & 6.08 & 19.20 & 21.00 & 14.26 & 15.46 \\
\hline R5 & 0.18 & 0.12 & 36.20 & 16.00 & 1.03 & 1.10 & 7.40 & 6.60 & 11.20 & 5.96 & 36.20 & 16.00 & 26.79 & 12.07 \\
\hline R6 & 0.22 & 0.17 & 37.60 & 39.80 & 6.27 & 1.17 & 9.20 & 9.00 & 13.32 & 12.54 & 37.60 & 39.80 & 28.21 & 29.51 \\
\hline R7 & 0.24 & 0.24 & 40.60 & 40.20 & 1.43 & 1.33 & 9.80 & 8.20 & 13.02 & 12.49 & 40.60 & 40.20 & 30.15 & 29.77 \\
\hline $\mathrm{R} 8$ & 0.26 & 0.25 & 27.00 & 40.40 & 1.30 & 1.30 & 10.20 & 7.80 & 9.69 & 12.44 & 27.00 & 40.40 & 20.28 & 29.89 \\
\hline R9 & 0.29 & 0.25 & 15.40 & 26.20 & 1.37 & 1.23 & 11.00 & 8.60 & 7.01 & 9.07 & 15.40 & 26.20 & 11.97 & 19.60 \\
\hline R10 & 0.28 & 0.27 & 31.80 & 14.00 & 1.43 & 1.30 & 10.00 & 9.40 & 10.88 & 6.24 & 31.80 & 14.00 & 23.77 & 10.84 \\
\hline R11 & 0.20 & 0.21 & 37.60 & 32.00 & 1.80 & 1.50 & 8.20 & 5.40 & 11.95 & 9.78 & 37.60 & 32.00 & 27.90 & 23.66 \\
\hline $\mathrm{R} 12$ & 0.10 & 0.09 & 48.00 & 26.20 & 2.30 & 1.70 & 10.60 & 6.60 & 15.25 & 8.65 & 48.00 & 26.20 & 35.61 & 19.51 \\
\hline $\mathrm{R} 13$ & 0.17 & 0.16 & 65.00 & 48.80 & 2.90 & 3.33 & 12.20 & 8.60 & 20.07 & 15.22 & 65.00 & 48.80 & 48.10 & 36.15 \\
\hline R14 & 0.21 & 0.20 & 69.60 & 70.20 & 2.23 & 3.27 & 13.60 & 11.40 & 21.41 & 21.27 & 69.60 & 70.20 & 51.49 & 51.87 \\
\hline R15 & 0.07 & 0.07 & 47.20 & 50.00 & 6.00 & 5.57 & 15.40 & 32.60 & 17.17 & 22.06 & 47.20 & 50.00 & 35.51 & 38.64 \\
\hline R16 & 0.04 & 0.05 & 52.00 & 60.00 & 6.03 & 5.67 & 14.00 & 12.00 & 18.02 & 19.43 & 52.00 & 60.00 & 38.91 & 44.60 \\
\hline $\mathrm{R} 17$ & 1.50 & 1.53 & 38.80 & 41.40 & 1.63 & 1.50 & 1.84 & 1.00 & 10.94 & 11.36 & 38.80 & 41.40 & 39.56 & 30.36 \\
\hline R18 & 1.75 & 1.84 & 21.00 & 36.00 & 0.93 & 1.73 & 1.92 & 2.80 & 6.40 & 10.59 & 21.00 & 36.00 & 21.48 & 26.54 \\
\hline R19 & 1.02 & 1.15 & 16.00 & 27.60 & 1.20 & 2.07 & 1.76 & 3.00 & 4.99 & 8.45 & 16.00 & 27.60 & 16.39 & 20.41 \\
\hline R20 & 0.91 & 1.33 & 39.80 & 52.00 & 1.10 & 1.50 & 2.00 & 2.40 & 10.95 & 14.31 & 39.80 & 52.00 & 40.55 & 38.14 \\
\hline R21 & 1.30 & 1.66 & 40.20 & 54.00 & 1.17 & 1.83 & 3.00 & 3.60 & 11.42 & 15.27 & 40.20 & 54.00 & 41.00 & 39.68 \\
\hline R22 & 1.76 & 1.81 & 40.40 & 58.40 & 1.33 & 2.07 & 2.64 & 5.00 & 11.53 & 16.82 & 40.40 & 58.40 & 41.22 & 42.97 \\
\hline R23 & 1.90 & 1.96 & 26.20 & 38.80 & 1.30 & 1.87 & 2.30 & 3.80 & 7.93 & 11.61 & 26.20 & 38.80 & 26.79 & 28.64 \\
\hline $\mathrm{R} 24$ & 1.85 & 2.14 & 14.00 & 22.20 & 1.23 & 1.67 & 1.90 & 5.20 & 4.75 & 7.80 & 14.00 & 22.20 & 14.40 & 16.64 \\
\hline $\mathrm{R} 25$ & 1.99 & 2.06 & 32.00 & 45.80 & 1.63 & 2.07 & 3.12 & 5.80 & 9.69 & 13.93 & 32.00 & 45.80 & 32.72 & 33.85 \\
\hline R26 & 1.56 & 1.51 & 26.20 & 54.00 & 1.20 & 1.60 & 4.20 & 5.60 & 8.29 & 15.68 & 26.20 & 54.00 & 26.85 & 39.76 \\
\hline R27 & 0.67 & 0.75 & 48.80 & 69.00 & 1.70 & 1.97 & 3.80 & 4.80 & 13.74 & 19.13 & 48.80 & 69.00 & 49.76 & 50.63 \\
\hline R28 & 1.17 & 1.24 & 70.20 & 93.40 & 3.33 & 4.00 & 2.70 & 6.00 & 19.35 & 26.16 & 70.20 & 93.40 & 71.52 & 68.59 \\
\hline & & & & & & & Mean CI & & 11.53 & 12.79 & Mean PI & & 31.30 & 30.48 \\
\hline
\end{tabular}

Fig. 4 Variation of PI in preand post-monsoon months

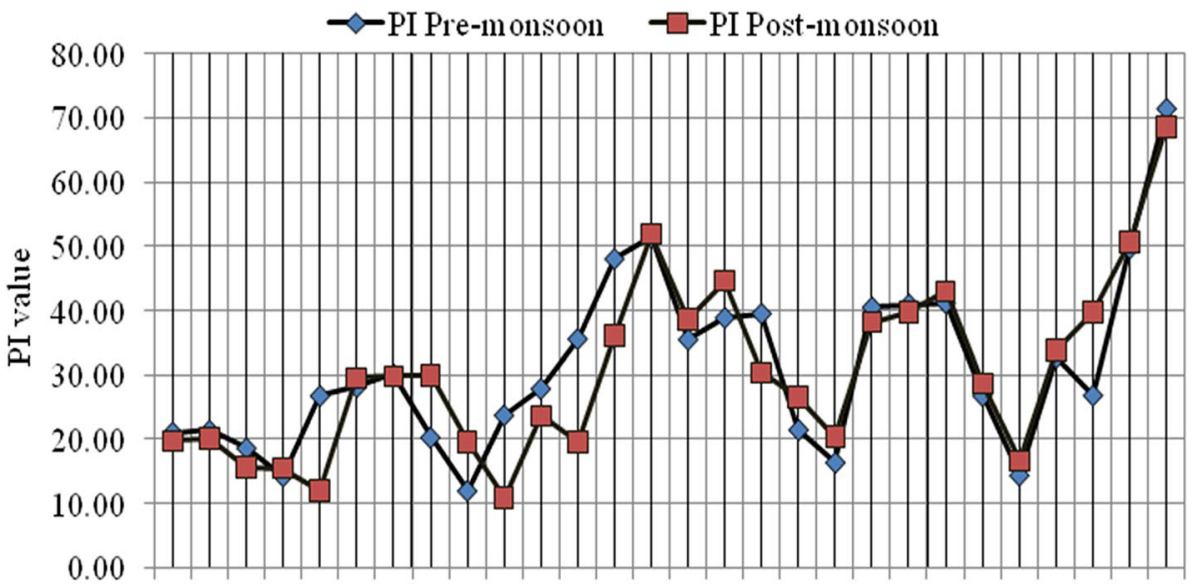

$\begin{array}{llllllllllllllllllllllll}\text { R1 } & \text { R3 } & \text { R5 } & \text { R7 } & \text { R9 } & \text { R11 } & \text { R13 } & \text { R15 } & \text { R17 } & \text { R19 } & \text { R21 } & \text { R23 } & \text { R25 } & \text { R27 }\end{array}$ Sampling locations 
works of life (Suthar et al. 2009; Jain and Sharma 2001; Chabukdhara and Nema 2012; Mishra et al. 2015).

\section{Inter-metal relationships}

To know the inter-metal interactions, Pearson correlation coefficient was performed using the raw data of heavy metal concentration in the studied stretch of Hindon River (Table 3). This relationship could be used to demonstrate the transport pathways and further know the input sources (here heavy metals) present in the river ecosystem (Chabukdhara and Nema 2012). The correlation coefficient $\left(R^{2}\right)$ values indicate a clear pattern of relationship among the heavy metals. The results reveal that in pre-monsoon months, the heavy metals like $\mathrm{Cu}-\mathrm{Cr}$, $\mathrm{Cu}-\mathrm{Fe}$ and $\mathrm{Cr}-\mathrm{Fe}$ gained a strong positive relationship, while $\mathrm{Zn}-\mathrm{Cu}$ showed a slight positive correlation coefficient (0.15). Moreover, $\mathrm{Zn}$ exhibited a negative relationship with $\mathrm{Fe}(-0.21)$ and $\mathrm{Cr}(-0.72)$. Similarly, a strong positive relationship was observed among $\mathrm{Fe}, \mathrm{Cu}$ and $\mathrm{Cr}$, whereas the negative relationship with $\mathrm{Zn}$ during post-monsoon months. The strong correlations coefficients among the metals indicate their common input sources and similar geochemical characteristics. The variation in the correlations coefficient between $\mathrm{Zn}-\mathrm{Cu}$ in the sampling period might be due to the direct discharge of untreated wastewater in the river from electroplating industrial sources. The negative relationship between $\mathrm{Zn}-\mathrm{Fe}$ and $\mathrm{Zn}-\mathrm{Cr}$ might be due to their difference in origin, characteristics and input source in the river water.

\section{Input source identifications}

The PCA technique was performed to identify the source of pollution (here heavy metals) and to extract more reliable information for a better demonstration of the relationship. Primarily, Kaiser-Meyer-Olkin (KMO) and Bartlett's tests were carried out using raw heavy metal data for both pre- and post-monsoon months. The impact of underlying factors on sampling adequacy or the proportion of common variance in estimated heavy metals data could be verified by the KMO value (Mishra et al. 2018). The high KMO value $\sim 1$ signifies the suitability of factor analysis for use, whereas $\mathrm{KMO}<0.5$ indicates the nonsignificant error in the estimated data. KMO was found as 0.522 and 0.518 with a significance level of 0.00 in Bartlett's tests of sphericity during pre- and postmonsoon months, respectively. The significance value close to 0.00 indicates significant factorial relationships). The PCA (with Varimax normalized rotation) of heavy metal datasets exhibited two PCs with eigenvalues $>1$, indicating 81.4 and

Table 3 Pearson's correlation coefficients of heavy metals during pre- and post-monsoon months, 2013-14

\begin{tabular}{cccccccccccc}
\hline Post-monsoon & $\mathrm{Zn}$ & $\mathrm{Cu}$ & $\mathrm{Fe}$ & $\mathrm{Cr}$ & Pre-monsoon & $\mathrm{Zn}$ & $\mathrm{Cu}$ & $\mathrm{Fe}$ & $\mathrm{Cr}$ \\
\hline \multirow{6}{*}{ Correlation } & $\mathrm{Zn}$ & 1.00 & - & - & - & Correlation & $\mathrm{Zn}$ & 1.00 & - & - & - \\
& $\mathrm{Cu}$ & -0.15 & 1.00 & - & - & & $\mathrm{Cu}$ & 0.15 & 1.00 & - & - \\
& $\mathrm{Fe}$ & -0.28 & 0.69 & 1.00 & - & & $\mathrm{Fe}$ & -0.21 & 0.36 & 1.00 & - \\
& $\mathrm{Cr}$ & -0.56 & 0.30 & 0.67 & 1.00 & & $\mathrm{Cr}$ & -0.72 & 0.06 & 0.45 & 1.00 \\
\hline
\end{tabular}
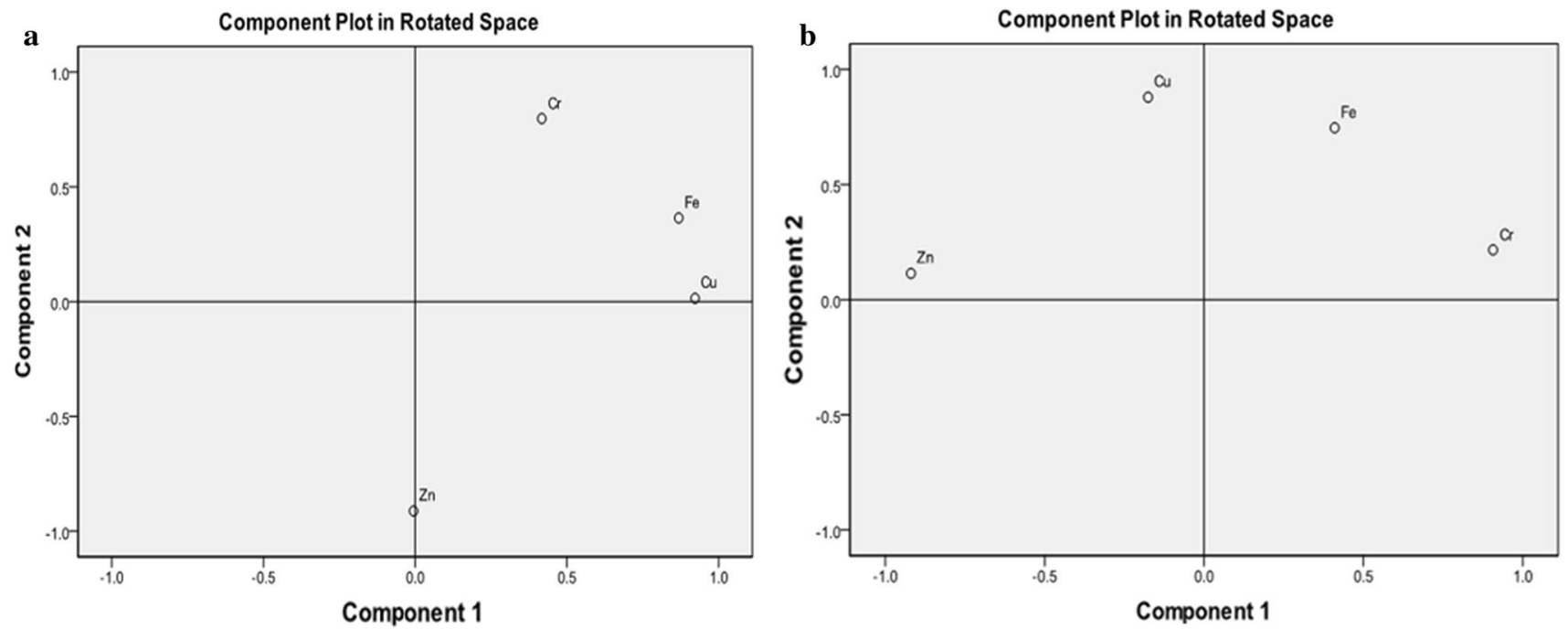

Fig. 5 PCA loadings and score plot of heavy metal during: a pre-monsoon months; $\mathbf{b}$ post-monsoon months 
Table 4 PCA components values of heavy metals

\begin{tabular}{lcrrrr}
\hline Heavy metals & \multicolumn{2}{l}{$\begin{array}{l}\text { PCA components during } \\
\text { post-monsoon }\end{array}$} & & \multicolumn{2}{l}{$\begin{array}{l}\text { PCA components } \\
\text { during pre-monsoon }\end{array}$} \\
\cline { 2 - 3 } \cline { 5 - 6 } & 1 & 2 & & 1 & 2 \\
\hline $\mathrm{Fe}$ & 0.89 & 0.30 & & 0.92 & -0.15 \\
$\mathrm{Cr}$ & 0.84 & -0.33 & & -0.80 & 0.46 \\
$\mathrm{Cu}$ & 0.70 & 0.60 & & 0.67 & 0.53 \\
$\mathrm{Zn}$ & -0.60 & 0.68 & & 0.18 & 0.88 \\
\hline
\end{tabular}

$84.45 \%$ of cumulative variance during pre- and post-monsoon months, respectively, as shown in Fig. 5.

The PCA results of heavy metals raw data for post-monsoon months are represented in Table 4. The PC1 explained $59.01 \%$ of the total variance and exhibited strong positive loadings of $\mathrm{Fe}, \mathrm{Cr}$ and $\mathrm{Cu}$, while strongly negative loading of $\mathrm{Zn}$. Moreover, PC2 explained $25.41 \%$ of total variance, showed positive loading of $\mathrm{Fe}, \mathrm{Zn}$ and $\mathrm{Cu}$, whereas $\mathrm{Cr}$ showed negative loading. Similarly, for pre-monsoon months, the PC1 explained $49.21 \%$ of total variance and exhibited strong positive loadings of $\mathrm{Fe}, \mathrm{Cu}$ and $\mathrm{Zn}$, while strongly negative loading of $\mathrm{Cr}$. Moreover, $\mathrm{PC} 2$ explained $32.20 \%$ of total variance, in which only Fe exhibited the negative loading and the others exhibited positive loading. The results indicate that the main input sources of these heavy metals ( $\mathrm{Fe}, \mathrm{Cu}$ and $\mathrm{Zn}$ ) could be the untreated wastewater entering into the river from industrial and urban areas. The wastewater might contain enter in the Hindon River from industries such as electroplating, steel, pharmaceuticals, textile, paper and pulp. The $\mathrm{Cu}$ loading in PC1 and PC2 of both pre- and post-monsoon months was strongly positive, which depicts that the river water received effluents from the chemical industries.

The variation in the loading of $\mathrm{Cr}$ in $\mathrm{PC} 1$ and $\mathrm{PC} 2$ for both sampling months could be due to its mixed origin, which indicates the contribution of $\mathrm{Cr}$ in the studied stretch of Hindon River could be from industrial or urban discharges and geomorphologic aging of parental rocks. Comparably, the Fe loading in PC1 and PC2 in post-monsoon was found strongly positive than pre-monsoon months, which indicates the addition of $\mathrm{Fe}$ into the river from lithogenic and anthropogenic sources. The heavy metal $\mathrm{Zn}$ was positively loaded in PCs of pre-monsoon months, whereas negative in PC1 and positive in $\mathrm{PC} 2$ of post-monsoon indicate that the $\mathrm{Zn}$ loading could be due to the industrial source. The impact of contamination from industrial sources was more during premonsoon than post-monsoon months. The $\mathrm{Cr}$ and $\mathrm{Fe}$ mentioned earlier may have different sources of origin, which could cause difficulty to control the effect of PC1 and PC2 by natural factors. The PCA results were very much supportive of water quality status classified as per PI values. However, it cannot be predicted with certainty (the level of metal contamination in river water) because the concentration of many heavy metals (other than those considered in the present study) has not been analyzed yet.

From the above analysis, it is found that water quality of Hindon River is unsuitable for drinking and other life-supporting activities. The river water should be pre-treated (e.g., technologies like reverse osmosis, ultrafiltration, ion exchange, membrane separation, etc.) and others for hygiene before used for drinking. Additionally, it is also suggested that the pre-treatment of industrial wastewater should be done before discharge into the river to maintain the aesthetic value of the river and aquatic life. These measures need to be taken into consideration by industries available in the vicinity of river catchment followed by governing authorities to mitigate the further deterioration of the river water quality and to restore the ecological assimilative capacity of the river.

\section{Conclusion}

The present study was carried out to assess the heavy metals $(\mathrm{Cu}, \mathrm{Fe}, \mathrm{Cr}$ and $\mathrm{Zn})$ concentration in the subsurface water of Hindon River and its stretches (at 28 sampling locations) during pre- and post-monsoon months. The raw datasets were used to evaluate the pollution index (PI) and further classify the overall metal contamination followed by PCA to know the pollution sources. The average PI value was evaluated as 31.30 and 30.48 during pre- and post-monsoon, respectively, which indicates the severe metal contamination in the river water and not fit for drinking or any other life-supporting activities. Pearson's correlation analysis of heavy metals showed a strong mutual dependency and common input source in the river water. Moreover, PCA results reveal that $\mathrm{Cu}$ impacts more to the water quality compared to $\mathrm{Fe}, \mathrm{Zn}$ and $\mathrm{Cr}$. This metal contamination is due to the inflow of partial/untreated wastewater from industrial, agricultural, domestic and saline seeps into the river. Thus, it is suggested to check each point and nonpoint source and pre-treated before discharge to the river. Moreover, catchment area treatment plans should be implemented in advance by the policy-makers and stakeholders to maintain the aesthetic value and ecological life.

Acknowledgements The authors are thankful to the Ministry of Human Resource and Development (MHRD), Government of India, for financial assistance in the form of academic scholarship and also thankful to Dr. M.K Singhal (Associate Professor, DHRE, IITR) for his help in sampling and laboratory testing.

\section{Compliance with ethical standards}

Conflict of interest Authors declare that they have no conflict of interest.

Open Access This article is licensed under a Creative Commons Attribution 4.0 International License, which permits use, sharing, adaptation, distribution and reproduction in any medium or format, as long as you give appropriate credit to the original author(s) and the source, 
provide a link to the Creative Commons licence, and indicate if changes were made. The images or other third party material in this article are included in the article's Creative Commons licence, unless indicated otherwise in a credit line to the material. If material is not included in the article's Creative Commons licence and your intended use is not permitted by statutory regulation or exceeds the permitted use, you will need to obtain permission directly from the copyright holder. To view a copy of this licence, visit http://creativecommons.org/licenses/by/4.0/.

\section{References}

Adimalla N (2020) Assessment and mechanism of fluoride enrichment in groundwater from the hard rock terrain: a multivariate statistical approach. Geochem Int 58(4):456-471

Alves RIS, Sampaio CF, Nadal M, Schuhmacher M, Domingo JL, Segura-Muñoz SI (2014) Metal concentrations in surface water and sediments from Pardo River, Brazil: human health risks. Environ Res 133:149-155. https://doi.org/10.1016/j.envres.2014.05.012

American Public Health Association (APHA) (2011) AWWA and WPCF standard methods for the examination of waters and waste waters. $22^{\text {nd }}$ ed. Washington DC

Barnwal B, Mishra S, Singhal SK (2015) Risk assessment and analysis of water quality in Ramgarh Lake, India. J Integr Sci Technol 3:22-27

Bureau of Indian Standards (BIS: 10500) (2012) Indian standard specification for drinking water. Second Revision. New Delhi

Chabukdhara M, Nema AK (2012) Assessment of trace metal contamination in Hindon River sediments: a chemometric and geochemical approach. Chemosphere 87:945-953

Dalakoti H, Mishra S, Chaudhary M, Singal SK (2018) Appraisal of water quality in the Lakes of Nainital District through numerical indices and multivariate statistics. India Int J River Basin Manag 16(2):219-229

Islam MS, Uddin MK, Tareq SM, Shammi M et al (2015) Alteration of water pollution level with the seasonal changes in mean daily discharge in three main rivers around Dhaka City, Bangladesh. Environments 2:280-294

Jain CK, Sharma MK (2001) Distribution of trace metals in Hindon River system, India. J Hydrol 253:80-90

Jose AL, Carolina M, Manuel GV, Moreno M (2014) Multi-way analysis for decadal pollution trends assessment: the Guadalquivir River estuary as a case study. Chemosphere 111:47-54

Kaushik A, Kansal A, Meena S, Kumari S, Kaushik CP (2009) Trace metal contamination of river Yamuna, Haryana, India: asessment by metal enrichment factor of the sediments. J Haz Mat $164: 265-270$

Kumar A, Mishra S, Kumar A, Singhal S (2017) Environmental quantification of soil elements in the catchment of hydroelectric reservoirs in India. Hum Ecol Risk Assess 23:1202-1218

Kumar A, Sharma MP, Rai SP (2017) A novel approach for river health assessment of Chambal using fuzzy modeling. India Desalination Water Treat 58(60):72-79

Kumar A, Sharma MP, Taxak AK (2017) Analysis of water environment changing trend in Bhagirathi tributary of Ganges in India. Desalination Water Treat 63:55-62

Kumar A, Kumar A, MMS CP, Chaturvedi AK et al (2020) Lead toxicity: health hazards, influence on food chain and sustainable remediation approaches. Int J Env Res Public Health 17:2179

Kumar A, Subrahmanyam G, Mondal R et al (2020) Bio-remediation approaches for alleviation of cadmium contamination in natural resources. Chemosphere. https://doi.org/10.1016/j.chemospher e.2020.128855.2020

Kumar A, Pinto MC, Kumar A, Kumar M, Dinis PA (2020) Estimation of risk to the eco-environment and human health of using heavy metal in the Uttarakhand Himalaya, India. Appl Sci 10(20):7078. https://doi.org/10.3390/app10207078

Lasagna M, De Luca DA, Debernardi L et al (2013) Effect of the dilution process on the attenuation of contaminants in aquifers. Environ Earth Sci 70:2767-2784

Lone SA, Bhat SU, Hamid A et al (2020) Quality assessment of springs for drinking water in the Himalaya of South Kashmir India. Environ Sci Pollut Res. https://doi.org/10.1007/s11356-020-10513-9

Misaghi F, Delgosha F, Razzaghmanesh M, Myers B (2017) Introducing a water quality index for assessing water for irrigation purposes: a case study of the Ghezel Ozan River. Sci Total Environ 589:107-116

Mishra S, Kumar A (2020) Estimation of physicochemical characteristics and associated metal contamination risk in river Narmada. India Env Eng Res 26:190521. https://doi.org/10.4491/ eer.2019.521

Mishra S, Kumar A, Shukla P (2015) Study of water quality in Hindon River using pollution index and environmetrics India. Desalination Water Treat. https://doi.org/10.1080/19443994.2015.1098570

Mishra S, Sharma MP, Kumar A (2016a) Pollution characteristic and health risk assessment of toxic chemicals of surface water in Surha Lake. India J Mater Env Sci 7(3):799-807

Mishra S, Sharma MP, Kumar A (2016b) Ecological health assessment of Surha Lake. India J Mater Env Sci 7(5):1708-1715

Mishra S, Kumar A, Yadav S, Singhal MK (2018) Assessment of heavy metal contamination in water of Kali river using principle component and cluster analysis, India. Sustain Resour Manage 4:573-581

Nur AS, Ahmad ZA, Hazzeman H (2015) Geoaccumulation and distribution of trace metals in the urban river sediment. Int J Sediment Res 29:368-377

Simeonov V, Simeonova P, Tsitouridou R (2004) Chemometric quality assessment of surface waters: two case studies. Chem and Eng Ecol 11:449-469

Singh V, Sharma MP, Sharma S, Mishra S (2019) Bio-assessment of River Ujh using benthic macro-invertebrates as bioindicators, India. Int J River Basin Manag 17:79-87

Singh P, Kumar A, Mishra S (2020) Performance evaluation of conservation plan for freshwater lakes in India through a scoring methodology. Environ Dev Sustain. https://doi.org/10.1007/s1066 8-020-00744-8

Suthar S, Nema AK, Chabukdhara M, Gupta SK (2009) Assessment of metals in water and sediments of Hindon River, India: Impact of industrial and urban discharges. J Hazard Mat 171:1088-1095

Turunen K, Räsänen T, Hämäläinen E et al (2020) Analysing contaminant mixing and dilution in river waters influenced by mine water discharges. Water Air Soil Pollut 231:317. https://doi.org/10.1007/ s11270-020-04683-y

Vink R, Behrendt H, Salomons W (1999) Development of the trace metal pollution trends in several European rivers: an analysis of point and diffuse sources. Water Sci Tech 39(12):215-223

Wang G, Yinglan A, Jiang H, Fu Q, Zheng B (2015) Modeling the source contribution of trace metals in surface sediment and analysis of their historical changes in the vertical sediments of a drinking water reservoir. J Hydrol 520:37-51

World Health Organization (WHO) (2017) Guidelines for drinking-water quality: fourth edition in corporating the first addendum. Geneva: Licence: CC BY-NC-SA 3.0 IGO. ISBN 978-92-4-154995-0

Yang CL, Guo RP, Yue QL, Zhou K, Wu ZF (2013) Environmental Quality Assessment and Spatial Pattern of Potentially Toxic Elements in Soils of Guangdong Province, China. Env Earth Sci 70:1903-1910

Publisher's Note Springer Nature remains neutral with regard to jurisdictional claims in published maps and institutional affiliations.

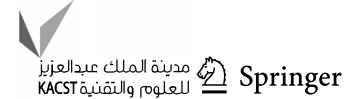

